\title{
Strategi Peningkatan Usaha Kecil Mikro dan Menengah (UMKM) di Era Pandemi Covid-19 Pada Kota Metro
}

\author{
Sigit Setioko ${ }^{1 *}$, Yuyun Fitriani ${ }^{2}$, Kholifatul Munawaroh ${ }^{3}$ \\ 1,2,3 Jurusan Ilmu Administrasi Publik, STISIPOL Dharma Wacana \\ 11sigitsetioko8@gmail.com, ${ }^{2}$ yuyunfitriani01.yf@gmail.com, ${ }^{3}$ nurmunawaroh8@gmail.com
}

\begin{abstract}
This paper outlines the formulation of strategies for small, Usaha kecil mikro dan menengah (UMKM) in the era of the Covid19 pandemic in Metro City, where very tight business competition and declining public income as a result of the Covid-19 pandemic forced entrepreneurs to apply the best strategic management to deal with current economic downturn. The target of the service activity is MSME Metro actors who are affected by the COVID-19 pandemic, then UMKM actors are asked to fill out pre-test and post-test, then the data is processed, so as to produce data in the form of a description of the explanation of internal environmental studies in increasing the capacity of Metro City UMKM actors in improving business opportunities during the pandemic. The author describes the analysis of strategies that can be divided into 2, namely the analysis of internal factors and analysis of external factors. Internal factor analysis will discuss further the strengths and weaknesses of the business and external factor analysis will discuss opportunities and threats that can occur in the company. Internal and external factors of strategic management are usually acronymized as SWOT (Strength, Weakness, Opportunity, Threath). to support efforts to increase income during the pandemic through internal environmental scanning efforts. Although this commitment is informal and has not yet formed a Memorandum of Understanding (MoU).
\end{abstract}

Keywords : Strategic Management, Internal Environment, Strategy Analysis

\begin{abstract}
Abstrak
Tulisan ini mengurai perumusan strategi bagi usaha kecil mikro dan menengah (UMKM)di era pandemi Covid-19 pada Kota Metro, dimana Persaingan usaha yang sangat ketat dan menurunnya pendapatan masyarakat sebagai dampak dari pandemic Covid-19 membuat pengusaha harus menerapkan manajemen strategi terbaik untuk menghadapi penurunan ekonomi saat ini. Sasaran kegiatan pengabdian adalah pelaku UMKM Metro yang terdampak pandemi covid-19, kemudian pelaku UMKM diminta untuk mengisi pre test dan post test, kemudian data tersebut diolah, sehingga menghasilkan data berupa uraian penjelasan tentang telaah lingkungan internal dalam peningkatan kapasitas pelaku UMKM Kota Metro dalam meningkatkan peluang bisnis dimasa pandemi. Tulisan ini menguraikan analisis strategi yang dapat dibedakan menjadi 2, yakni analisis faktor internal dan analisis faktor eksternal. Analisis faktor internal akan membahas lebih lanjut mengenai kekuatan dan kelemahan usaha dan analisis faktor eksternal membahas mengenai peluang dan ancaman yang dapat terjadi pada perusahaan. Faktor internal dan eksternal manajemen strategi biasanya diakronimkan dengan sebutan SWOT (Strenght, Weakness, Opportunity, Threath).Dalam penulisan artikel ini, akan lebih fokus membahas mengenai telaah lingkungan internal dalam peningkatan kapasitas pelaku UMKM Kota Metro dalam meningkatkan peluang bisnis dimasa pandemic dengan membentuk komitmen untuk mendukung upaya peningkatan pendapatan di masa pandemic melalui upaya scanning lingkungan internal.Meskipun komitmen ini bersifat informal dan belum terbentuk Memorandum of Understanding (MoU).
\end{abstract}

Kata Kunci: Manajemen Strategi, Lingkungan Internal, Analisis Strategi

*Penulis Korespondensi : Sigit Setioko 


\section{Pendahuluan}

Usaha Mikro Kecil dan Menengah (UMKM) merupakan kelompok usaha yang memiliki jumlah paling besar.Selain itu kelompok ini terbukti tahan terhadap berbagai macam goncangan krisi ekonomi.Maka sudah menjadi keharusan penguatan kelompok Usaha Mikro Kecil dan Menengah yang melibatkan banyak kelompok(Beirne et al., 2020). Dalam masa pandemi saat ini Usaha Mikro Kecil Menengah (UMKM) tidak dapat dilepaskan dari terdampaknya pandemi Covid-19. Usaha Mikro Kecil Menengah (UMKM) harus dapat bertahan dimasa pandemi saat ini yang mana dituntun harus mempunyai inovasi lebih untuk meningkatkan daya jual ke masyarakat dengan tetap terus mematuhi protokol kesehatan

Keberlangsungan UMKM dalam menghadapi pandemi tidak terlepas dari tujuan perusahaan yakni kepuasan konsumen atau pelanggan dapat dicapai melalui perumusan strategi yang baik. Perumusan strategi didefinisikan sebagai suatu proses dalam menyusun langkah-langkah untuk pengembangan perusahaan, seperti penetapan tujuan perusahaan dan pencapaian visi dan misi perusahaan. Penetapan strategi haruslah melihat latar belakang dan tujuan perusahaan agar strategi yang ditentukan dapat dijalankan dan membawa dampak positif bagi pengembangan perusahaan.Selain berfokus pada penelaahan tujuan perusahaan, penetapan strategi juga harus memperhatikan faktor lingkungan.Analisis lingkungan bermanfaat bagi pengembangan perusahaan karena apabila perusahaan melakukan analisis lingkungan dengan benar maka perusahaan dapat mengambil tindakan preventif atau antisipasi atas perubahan yang terjadi di lingkungan perusahaan. Dampak positif dari kemampuan perusahaan melakukan analisis lingkungan adalah perusahaan dapat beradaptasi dengan baik saat terjadi perubahan lingkungan (Setiyawan, 2013).

Salah satu sektor usaha yang mempunyai peranan besar dalam pertumbuhan ekonomi dan pembangunan nasional adalah Usaha Kecil Mikro dan Menengah (UMKM).UMKM juga mampu menyerap tenaga kerja guna mengurangi angka pengangguran yang semakin
tinggi.Tenaga kerja yang diberdayakan dalam pengembangan UMKM biasanya adalah tenaga kerja yang bertempat tinggal tidak jauh dari lokasi UMKM berdiri sehingga keberadaan UMKM mampu turut serta meningkatkan taraf hidup dan kesejahteraan masyarakat sekitar.Namun, perkembangan UMKM di Indonesia sering digambarkan sebagai usaha skala kecil yang sulit untuk tumbuh dan berkembang karena latar belakang pendidikan dan skill yang dimiliki oleh pengelola UMKM rendah.(Beirne et al., 2020)

Salah satu organisasi yang menjadi wadah berkembangnya UMKM adalah Genpro (Generasi Produktif).Genpro tersebar dihampir seluruh wilayah Indonesia, tidak terkecuali di Kota Metro.Genpro Kota Metro membawahi kurang lebih sekitar 35 UMKM yang bergerak dalam bidang makanan, Wedding Organizer, dan lain sebagainya.Seiring dengan datangnya pandemi Covid-19 omset yang didapat oleh para pelaku usaha semakin menurun setiap harinya. Sehingga perlu dilakukan analisis mendalam mengenai manajemen strategi dari usaha yang digeluti oleh masing-masing anggota.

Perkembangan sebuah usaha pasti tidak terlepas dari manajemen strategi yang diterapkan dalam perusahaan tersebut.Manajemen strategi mencakup banyak hal diantaranya kegiatan perencanaan, pengorganisasian, pengarahan dan pengawasan.Setiap perusahaan memiliki manajemen strategi yang berbeda meskipun jenis usaha yang dikembangkan memiliki kesamaan, misalnya usaha kuliner dengan spesifikasi oleh-oleh khas Lampung. Tentunya perusahaan A dan perusahaan $\mathrm{B}$ memiliki strategi masing-masing dalam mengelola usahanya mulai dari strategi marketing, strategi pemilihan lokasi usaha hingga ke desain produk yang berbeda. Strategi yang di terapkan di setiap perusahaan bertujuan untuk mengembangkan usahanya (Nilasari, 2014).

Persaingan usaha yang sangat ketat dan menurunnya pendapatan masyarakat sebagai dampak dari pandemic Covid-19 membuat pengusaha harus menerapkan manajemen strategi terbaik untuk menghadapi penurunan ekonomi saat ini.Analisis strategi dapat dibedakan menjadi 2 , yakni analisis strategi dalam segi faktor internal dan analisis faktor 
eksternal. Analisis faktor internal akan membahas lebih lanjut mengenai kekuatan dan kelemahan usaha dan analisis faktor eksternal membahas mengenai peluang dan ancaman yang dapat terjadi pada perusahaan. Faktor internal dan eksternal manajemen strategi biasanya diakronimkan dengan sebutan SWOT (Strenght, Weakness, Opportunity, Threath).

\section{Metode}

Program pengabdian pada masyarakat yang diusulkan adalah memberikan pelatihan mengenai tata cara membuat desain barang untuk penjualan online agar lebih menarik. Pengumpulan data dilakukan melalui kegiatan pengabdian yang dilaksanakan pada tanggal 8 November 2020 di Aula STISIPOL Dharmawacana Metro dengan jumlah yang hadir sebanyak 20 orang yang terdiri dari pengurus dan anggota Genpro Chapter Metro. Teknik pengambilan sampel pada umumnya dilakukan secara random, pengumpulan data menggunakan instrumen penelitian berupa kuesioner yang dibagikan kepada peserta, analisis data bersifat kuantitatif atau statistik dengan tujuan untuk menguji dugaan sementara yang telah ditetapkan.(Sugiyono, 2018)

Metode evaluasi dilakukan dengan melalui kegiatan evaluasi kuantitatif melalui pre test dan post test. Evaluasi pre test dan post test dibutuhkan agar dapat mengukur perubahan kemampuan dan pengetahuan peserta sebelum mengikuti seluruh rangkaian tahapan kegiatan dengan kemampuan peserta setelah mengikuti seluruh kegiatan. Evaluasi kedua dilakukan melalui refleksi atau evaluasi kualitatif. Evaluasi kualitatif dilakukan melalui kegiatan diskusi dan tanya jawab dengan pemateri khususnya yang terkait dengan aspek peningkatan kapasitas pelaku UMKM KotaMetro dalam meningkatkan peluang bisnis dimasa pandemi.

\section{Hasil dan Pembahasan}

Sebelum kegiatan pengabdian dilaksanakan, seluruh peserta mengerjakan pre test.Kegiatan ini dimaksudkan untuk mengukur pengetahuan peserta terhadap materi terkait telaah lingkungan internal bidang usahanya. Materi disampaikan dengan cara ceramah dan melibatkan peserta untuk berbagi cerita tentang pengalaman mereka dalam mengelola usaha. Dari berbagai cerita yang disampaikan oleh peserta, sehingga dapat disimpulkan bahwa peserta belum memahami dengan baik manajemen strategi yang tepat untuk mengelola usahanya.

Peserta program pengabdian diajak bersama-sama untuk menganalisis bagaimana kelemahan, dan kekuatan usaha yang dihadapi di masa pandemic. Sehingga berdasarkan hasil analisis peserta dapat disimpulkan bahwa kelemahan yang paling mendasar yang dialami oleh peserta dalam melakukan pengembangan usaha adalah kurangnya kemampuan peserta dalam mendesain produk sehingga berdampak pada kurangnya promosi usaha dan rendahnya daya jual produk. Rendahnya kemampuan tersebut dipengaruhi oleh faktor usia pelaku usaha karena rata-rata pelaku usaha adalah ibu-ibu dan bapak-bapak.

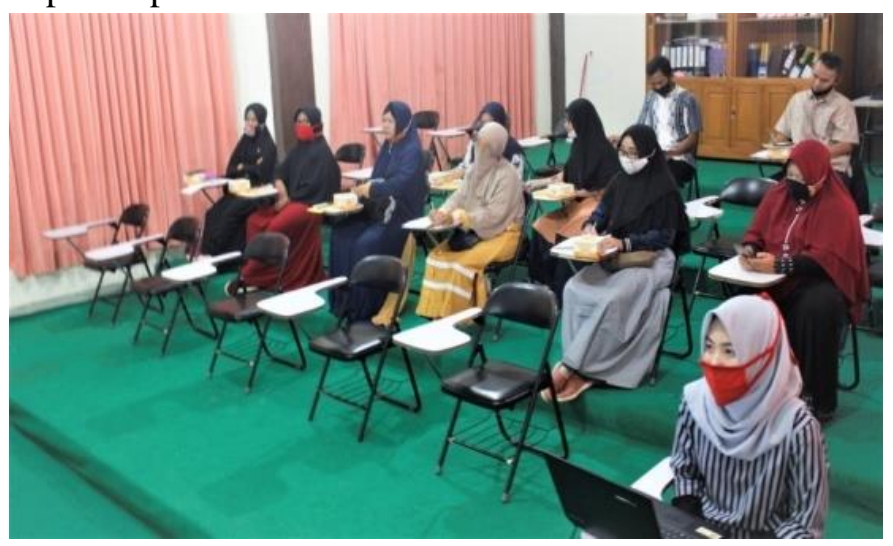

Gambar 1. Audiense Sedang Menyimak Materi

Gambar diatas menjelaskan bawa peserta menyimak dengan baik materi yang diberikan oleh pemateri. Setelah diberikan materi sesi pertama peserta mampu membedakan mana yang merupakan kekuatan dan kelemahan usahanya. Sehingga dapat dipetakan unsur apasajakan yang mendominasi usahanya.

Analisis situasi lingkungan internal dan eksternal.Lingkungan internal dapat dikelompokkan menjadi dua jenis yakni kekuatan dan kelemahan.Peserta diajak untuk bercerita mengenai kekuatan dan kelemahan usahanya.Berdasarkan hasil cerita dari peserta maka dapat disimpulkan bahwa tidak semua 
peserta memahami kekuatan dan kelemahan bidang usaha yang digelutinya.

Secara keseluruhan hasil pre test dan post test adalah sebagaimana tercantum pada tabel berikut ini:

Tabel 1. Hasil Pre Test dan Post Test

\begin{tabular}{|c|c|c|c|c|}
\hline No & Nama & $\begin{array}{l}\text { Pre } \\
\text { Test }\end{array}$ & $\begin{array}{l}\text { Post } \\
\text { Test }\end{array}$ & $\begin{array}{c}\text { Perubaha } \\
\text { n }\end{array}$ \\
\hline 1. & Siti Maryanti & 80 & 85 & 5 \\
\hline 2. & Heri Y & 60 & 75 & 15 \\
\hline 3. & Salsabila Nur A & 0 & 50 & 50 \\
\hline 4. & Agus Irawan & 0 & 85 & 85 \\
\hline 5. & Semiyati Handayani & 70 & 90 & 20 \\
\hline 6. & Pandu Eka Saputra & 70 & 70 & 0 \\
\hline 7. & Suwarso & 50 & 55 & 5 \\
\hline 8. & Isa Ansori & 80 & 80 & 0 \\
\hline 9. & Fani Ramadhan & 30 & 70 & 40 \\
\hline 10. & Banalinca & 70 & 80 & 10 \\
\hline 11. & Dwi Wijanarti & 70 & 80 & 10 \\
\hline 12. & Eka Sulastri & 0 & 80 & 80 \\
\hline 13. & Susi Dewi & 0 & 80 & 80 \\
\hline 14. & Lisdawati & 80 & 85 & 5 \\
\hline 15. & Amelia Nofiyanti & 60 & 80 & 20 \\
\hline 16. & Dwi Mulyanti & 70 & 70 & 0 \\
\hline 17. & Dwi Yunila Sari & 70 & 80 & 10 \\
\hline 18. & Ari Sulistyorini & 40 & 50 & 10 \\
\hline 19. & Sumaryanto & 30 & 50 & 20 \\
\hline \multirow[t]{2}{*}{20.} & Selly Oktavia & 70 & 70 & 0 \\
\hline & Rata-rata & 50 & 73,25 & 23,25 \\
\hline
\end{tabular}

Sumber: Hasil Pengabdian, 2020

Berdasarkan tabel diatas secara kuantitatif dapat didefinisikan bahwa nilai rata-rata peserta sebelum mengikuti kegiatan adalan 50 kemudian mengalami perubahan menjadi 73,25 setelah dilaksanakan kegiatan pelatihan. Kenaikan rata-rata sebesar 23,25 poin. Baik nilai pre test maupun post test tertinggi adalah 90 dan terendah adalah 0.Angka tersebut didapatkan setelah peserta menjawab daftar pertanyaan yang berfokus pada kekuatan dan kelemahan usahanya sebagai bentuk analisis situasi internal.

Analisis lingkungan internal terdiri atas dua hal.pertama, kekuatan(Strength), merupakan keadaan yang dianggap menguntungkan perusahaan karena berdampak positif bagi pengembangan perusahaan dalam pencapaian tujuan atau penambahan laba usaha. Strength harus dapat terdefinisikan dalam bentuk tindakan. Misalnya restoran dapat membrandingdirinya dengan layanan all you can eat. Sehingga konsumen dapat dengan mudah mengingat restoran tujuannya jika menginginkan restoran dengan sistem tersebut.Tindakan dan ingatan konsumen merupakan dampak positif dari pendefinisian kekuatan. Kedua, kelemahan (Weakness) merupakan situasi dan ketidakmampuan perusahaan yang berdampak pada tidak tercapainya tujuan perusahaan.Kelemahan membawa dampak negatif terhadap perkembangan perusahanaan maka seorang manajer harus dapat membaca kelemahan perusahaan dengan cepat agar dapat meminimalisir dampak negatif yang akan ditimbulkan.

Analisis lingkungan internal berfokus pada kekuatan dan kelemahan di lingkungan internal organisasi.Telaah Lingkungan Internal ini mencermati (scanning) terdiri atas beberapa hal, yakni sebagai berikut:(Akdon and Ridwan, 2006)

\section{a. Struktur Organisasi}

Menurut Gordon dalam Sugandi (2011:37-38), dalam organisasi lini dan staf, para manajer dibantu oleh staf yang memberikan tugas pembantuan dalam mencapai tujuan organisasinya. Tugas ini dapat berupa tugas memberikan masukan, nasihat,pengawasan, fasilitas, pengendalian, dan perwakilan. Namun dalam organisasi lini dan staf, para staf tidak memiliki staf lagi, para staf ini biasanya langsung mengerjakan hal-hal yang bersifat operasionalisasi. Kegiatan operasionalisasi ini biasanya dikerjakan dengan sangat rigid, dan perintah yang diberikan oleh atasan merupakan perintah yang bersifat langsung, staf ini biasanya diangkat berdasarkan atas keahlian yang dimiliki dan staf ini tidak memiliki otoritas dan hubungan langsung kepada bawahan, karena staf biasanya bekerja atas profesionalitasan dan kemampuan saja.

Dalam upaya peningkatan kapasitas pelaku UMKM Kota Metro dalam membaca peluang bisnis dimasa pandemipeningkatan struktur organisasi perlu ditingkatkan karena para pelaku UMKM belum memiliki struktur organisasi.Pelaku UMKM Kota Metro terdiri dari pelaku usaha kuliner, wedding organizer, obat herbal dan lain sebagainya.Pelaku UMKM rata-rata memiliki usaha rumahan sehingga tidak memiliki struktur oraganisasi yang jelas.Padahalstruktur organisasi sangat diperlukan untuk membagi pembagian 
tugas yang jelas.Tidak adanya struktur organisasi yang jelas menjadi salah satu kelemahan pelaku UMKM Kota Metro.

\section{b. Sistem Organisasi}

Sistem organisasi dibentuk atas dasar tujuan efektivitas organisasi.Dalam sistem organisasi menyebutkan bahwa efektivitas organisasi dapat dicapai apabila komunikasi internal berlangsung dengan baik.Pengimplementasian sistem organisasi dalam upaya peningkatan efektivitas organisasi dan efektivitas komunikasi internal pelaku UMKM Kota Metro belum berjalan dengan baik.Hal tersebut disebabkan oleh pelaku usaha yang belum memiliki struktur organisasi dan bentuk usahanya masih tergolong dalam usaha rumahan.Pelaku UMKM memiliki skala usaha yang masih kecil dan tujuan organisasi (usaha) belum mampu dipetakan dengan baik.

\section{c. Sumber Daya Manusia}

Sumber daya merupakan aset yang harus dikelola sesuai dengan kebutuhan perusahaan.Salah satu jenis sumber daya yang harus dapat dikelola dengan baik adalah sumber daya manusia. Menurut David (2011:93), mengelola sumber daya manusia yang baik dalam sebuah organisasi akan membuat organisasi lebih kebal terhadap persaingan. Perencanaan yang dibuat harus dapat dikerjakan dan dilakukan oleh tenaga ahli dan paham terhadap bidangnya. Pengelolaan sumber daya manusia dalam upaya pengembangan UMKM Genpro Chapter Metro belum dilaksanakan dengan baik karena rata-rata pelaku usaha sudah berusia diatas 30 tahun sehingga kecepatan dalam membaca keadaan dan memberikan pemikiran kritis serta tindakan preventif sangat kurang.

\section{d. Teknologi}

Globalisasi yang membawa arus perubahan teknologi dan telah digunakan sampai saat ini muncul di lingkungan internal organisasi sebagai bentuk dukungan terhadap proses kinerja atau misi organisasi. Kemajuan teknologi memberikan solusi dan memudahkan segala bentuk pekerjaan perusahaan agar lebih efisien dan efektif.Teknologi mengarahkan jenis usaha pada dua sisi yakni padat modal atau padat kerja.Perusahaan padat modal artinya diawal pembentukan perusahaan tersebut menginvestasikan sebagian besar modalnya pada pembelian alat atau mesin penunjang kerja perusahaan agar pekerjaan dapat diselesaikan dengan cepat. Perusahaan yang memilih menggunakan sistem padat modal tidak membutuhkan tenaga manusia dengan jumlah yang banyak. Kemudian, jenis perusahaan padat kerja adalah perusahaan yang lebih banyak menggunakan tenaga manusia dalam memproduksi barang atau jasanya.

Dalam konteks bisnis, teknologi membawa dampak transformasional dalam berbisnis.Salah satunya dalah berkembangnya sistem digital marketing atau internet marketing yang memanfaatkan internet sebagai media pasar. Digital marketingberkembang sangat pesat dan mendapatkan respon baik dari masyarakat. Pasar online mempermudah orang-orang yang ingin berbelanja namun tidak ingin berdesak-desakan di pasar atau supermarket. Transaksi dapat dilakukan dengan gadget pribadi dan sistem pembayarannya beranekaragam, bias melalui e-banking atau cash on delivery (COD).

Selain dari segi kemudahan transaksinya.Digital marketing juga mencakup kegiatan promosi.Promosi yang baik di media social harus mempertimbangkan pilihan kata, waktu pengunggahan gambar dan seberapa menarik desain produk yang ditampilkan. Menarik atau tidaknya desain produk akan sangat mempengaruhi keinginan konsumen untukmembeli produk yang dijual. Dari hasil pendampingan ini, telah dihasilkan produk dengan desain yang menarik. Kelompok Genpro Chapter Mentro telah memahami tata cara mendesain produk dengan baik dan langsung melakukan praktik mendesain. Tidak membutuhkan waktu yang lama untuk memberikan arahan desain produk karena kelompok Genpro Chapter Mentro telah memahami kelemahan dan ancamannya sehingga dapat memperbaiki desain usahanya dengan cepat.

Kegiatan pengabdian ini diakhiri dengan foto bersama antara pemateri dan Genpro Chapter Mentro di aula lokasi kegiatan. 


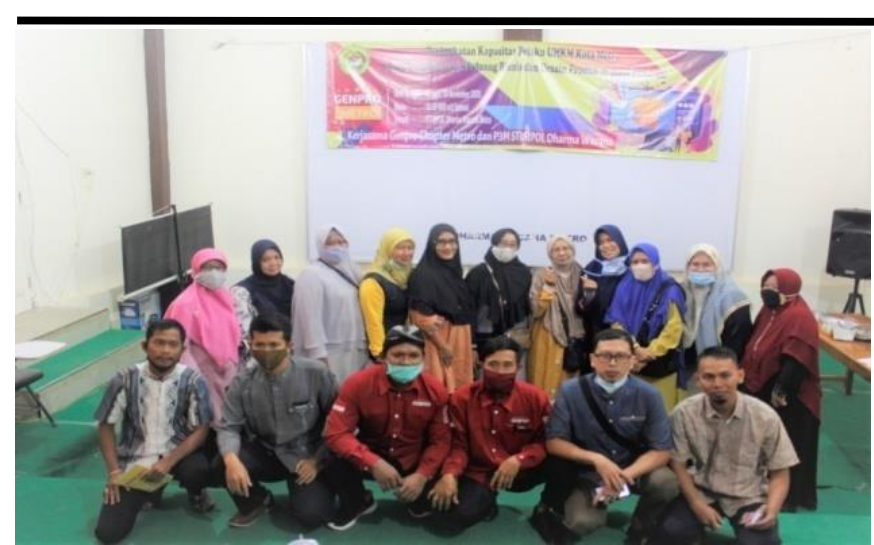

Gambar 2. Foto kegiatan

\section{Kesimpulan}

Kegiatan pengabdian ini mampu memberikan dampak positif secara kognitif terhadap pengetahuan tentang telaah lingkungan internal usaha.Sedangkan dari sisi afektif peserta menghasilkan komitmen untuk mendukung upaya peningkatan pendapatan udaha masa pandemic melalui upaya scanning lingkungan internal. Meskipun komitmen ini bersifat informal dan belum terbentuk MOU. Kegiatan pengabdian ini brdampak pada meningkatnya kemampuan kelompok sasaran dalam mendesain produk untuk kegiatan promosi usaha dan secara langsung berdampak pada kenaikan omset penjualan di masa pandemic. Kegiatan pengabdian ini dapat dilanjutkan dengan pengabdian yang sifatnya berkesinambungan dan efektif. Misalnya dalam bentuk pendampingan promosi produk oleh Genpro Chapter Metro. Sehingga diharapkan adanya peningkatan penghasilan pada pelaku UMKM di masa pandemi covid-19 dan menumbuhkan semangat berwirausaha bagi masyarakat.

\section{UCAPAN TERIMA KASIH}

Kami selaku pelaksana kegiatan menghaturkan rasa terima kasih kepada pihak terkait.Terutama kepada institusi yang mendukung kegiatan STISIPOL Dharma Wacana Metro dan kepada mitra kegiatan yakni Global Entrepreuner Profesional(GENPRO) Chapter Metro.

\section{DAFTAR PUSTAKA}

Akdon and Ridwan (2006) Aplikasi Statistika dan Metode
Penelitian Untuk Administrasi dan Manajemen, Bandung: Dewa Ruci.

Beirne, J. et al. (2020) 'Financial Market and Capital Flow Dynamics During the COVID-19 Pandemic', SSRN Electronic Journal. doi: 10.2139/ssrn.3656848.

Setiyawan (2013) 'Analisis Lingkungan Internal Dan Eksternal Dalam Menetapkan Strategi Untuk Keberlangsungan Hidup Perusahaan (Studi Kasus Pada Industri Rumah Tangga Keripik Tempe Ri-Mas Malang)', Journal of Chemical Information and Modeling.

Sugiyono, D. (2018) Metode penelitian kuatintatif, kualitatif dan $R \&$ D / Sugiyono, Bandung: Alfabeta.

Sugandi, Achmad, dkk.,(2011)Teori Pembelajaran. Unnes Press. Semarang. 